\title{
Soils swelling as a regional feature of Western Siberia
}

\author{
Dmitry Eremin ${ }^{1 * *}$ \\ ${ }^{1}$ The State Agrarian University of Northern Zauralye, 625003 Tyumen, Republic Street, 7. Russia,
}

\begin{abstract}
The research was to study the causes of soil swelling in Western Siberia. Studies were carried out on four stationary platforms in different climatic zones: from the sub-taiga to the southern forest-steppe. As a result of the research it was found that the level of the perched water is usually at a depth of 1-3 meters, which varies greatly depending on the season. The maximum elevation occurs at the beginning of summer, the beginning of winter - the depth of the perched water up to 3.0 meters or more. It was determined that in the sub-taiga zone of Western Siberia, perched water having a joint influence on the swelling soil; capillary fringe of perched water reaches a depth of $90 \mathrm{~cm}$ and the heterogeneity of the addition of the upper meter of the soil layer, which is formed by illuvial horizon with low filtration capacity. On soils with a uniform granulometric composition, despite the deeper occurrence of perched water, capillary fringe reaches a depth of $40 \mathrm{~cm}$, where it has the maximum effect on the soil swelling. During construction, it is necessary under the base of roads to create protective shields of fine gravel or substandard sand, preventing the rise of water and the manifestation of bulk soils swelling.
\end{abstract}

\section{Introduction}

The climate of Western Siberia is characterized by a long and severe winter period. This leads to the freezing of the soil to a greater depth. On average, the depth of soil freezing in Western Siberia varies from 50 to $250 \mathrm{~cm}$. Such a significant difference is due to both weather conditions and soil characteristics of the region. The combination of high freezing depth and high soil moisture leads to the formation of such phenomena as soil swelling. This process is studied in detail from a physical point of view, but few can give a universal recommendation to prevent swelling phenomena. The main swelling soils include watersaturated clay or heavy loam [1]. Increased humidity gives them the properties of soils with weak load-bearing capacity [2]. The use of such soils as a basis for roads, without proper techniques to prevent the occurrence of swelling, leads to serious destruction of the roadway or its slopes. The construction of the roadbed in such conditions forces the road builders to replace the weak ground base with the entire thickness of the sandy ground, which has a high filtration coefficient and a low capillary rise height $[3,4,5]$. This method of the roadbed building significantly increases the time and cost of roads construction.

\footnotetext{
*Corresponding author: soil-tyumen@yandex.ru
} 
A significant part of the roads of Western Siberia is subject to annual deformation as a result of soil swelling [6]. One of the reasons for the manifestation of soil swelling is considered to be high humidity, formed for various reasons. First of all, it should be noted weak evaporation due to low temperatures and the presence of large forests. Another reason is poor water permeability of soils, and in some cases - the lack of it. In Western Siberia, this leads to the formation of a special category of groundwater - perched water. It becomes the main reason for the formation of the swelling soil and has seriously hindered the construction of high-quality roads in Siberia. Perched water formed on nipped impermeable or low permeable rocks in the aeration zone by infiltration of precipitation and surface waters. Such conditions are usually created by occurrence of clay deposits among sands and sandy loam. As a result of modern soil-forming processes it is possible to meet creation of the illusory horizon which is characterized by extremely weak water permeability $[7,8,9]$. In the taiga zone of Western Siberia, the appearance of such aquicludes is considered common. The situation with surface overwetting and plain relief of Western Siberia is getting worse. On steep slopes, where precipitation is mainly spent on surface runoff and in small quantities on infiltration, perched water is usually absent. Favorable conditions for perched water throughout the year are created on the flat watershed spaces with saucer-like depressions. This leads not only to soil swelling, but also makes it weak and unfavorable from the point of road construction view.

The distinctive features of the perched water are: limited area distribution; rapid fluctuations in water level, composition and reserves; the lack of hydraulic connection with the rivers. The composition of the perched water is motley. In the Northern regions, it is fresh or slightly mineralized waters with a high content of organic substances, iron, silicic acids. In the forest-steppe and steppe - it can be salty, reaching a maximum value of mineralization $50 \mathrm{mg} / \mathrm{liter}$.

The purpose of researches. Study the natural conditions of the perched water formation in West Siberia and its role in the formation of swelling soils.

\section{Materials and Methods}

The study of the occurrence and mineralization of the perched water was carried out in 4 stationary platform located in different climatic zones. Tobolsk stationary platform (58004'41.47": 68004'41.47") located on light-gray gleyed soil. Tyumen stationary platform (57000'21.00": 65042'30.53"), located on grey forest gleyed soil. Jalutorovsk stationary platform located on the meadow malt soil, its coordinates- 56044'39.1": 66002'11.74". The extreme southern point of our research was the Berdjuzh'e stationary platform, which was formed on saline meadow soil (55041'15.90": 68039'07.33").

For research, bores with a diameter of $50 \mathrm{~mm}$ were drilled at each stationary platform to a depth of 3.5 meters, where perforated polyvinylchloride tubes of the same diameter were placed. Four bores were drilled at stationary platforms, which made it possible to carry out statistical processing of digital material. During drilling, samples of soils were selected to determine the granulometric composition, which was carried out in the cathedral laboratory of agrophysical properties on the laser granulometer Analisette-22. After sampling and measuring the depth of the perched water, the tubes were tightly closed with plugs. The studies were carried out in the period from 2010 to 2014. Measurement of the level of occurrence of perched water was made in the third week of each month. The concentration of water-soluble salts and their composition was determined in the water samples. Just before freezing the soil (the first decade of November) drilling was carried out to a depth of $150 \mathrm{~cm}$ to select the actual moisture content and establish the depth of the capillary fringe, 
formed over the perched water. Humidity determination was carried out by thermostatically-weight method.

\section{Results}

Prevailing in Western Siberia plain terrain, transit nature of rivers and poorly developed ravine-beam network cause a high level of groundwater occurrence, especially for low terraces of all geomorphological levels. Water-bearing rocks are sandy and loamy quaternary deposits. The capacity of such aquiferous horizon usually ranges from 3 to 12 metres. The degree of mineralization in the taiga zone does not exceed $0.6 \mathrm{~g} / \mathrm{l}$ and only in the forest-steppe zone can increase to $1.5 \mathrm{~g} / \mathrm{l}$. Underground waters are hydrocarbonatecalcium on their salt structure, in a forest-steppe zone it is possible to face also hydrocarbonate-sodium, chloride-sulfate with neutral or slightly alkaline reaction underground waters.

Perched water often occurs in large arrays on the flat plains and terraces of the watershed, occupying primarily eluvial-deluvial lenses of sands and sandy loams thickness of 2.5-3.0 meters, underlain by impermeable clays. The power of these lenses is mainly due to the precipitation, and only on the terraces of the lower levels groundwater involved. The level of perched water is usually found at depths of 1-3 meters, but, unlike groundwater, it is subject to significant seasonal fluctuations. (table.1). As L. N. Karetin noted, in dry years the level of perched water lowered to 5-6 meters, however, a complete disappearance occurs in exceptional cases [LINK_Karetin]. This feature of the moisture regime in combination with granulometric composition led to the formation of soil cover with different fertility levels $[10,11,12]$.

Table 1. Dynamics of the level of occurrence of perched water in various climatic zones of Western Siberia (2010-2014)

\begin{tabular}{|c|c|c|c|c|c|c|c|c|c|c|c|c|}
\hline $\begin{array}{l}\text { Stationary } \\
\text { platform }\end{array}$ & 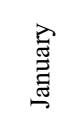 & 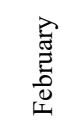 & 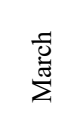 & $\begin{array}{l}\bar{E} \\
\bar{\alpha}\end{array}$ & $\sum^{\mathrm{I}}$ & 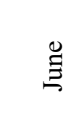 & $\stackrel{\gtrsim}{\Xi}$ & 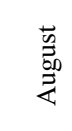 & $\begin{array}{l}\overline{0} \\
\overline{0} \\
\overline{0} \\
\overline{0}\end{array}$ & $\begin{array}{l}\overrightarrow{0} \\
\overrightarrow{0} \\
\overrightarrow{0} \\
0\end{array}$ & $\begin{array}{l}\bar{\Xi} \\
\bar{\Xi} \\
\text { ठे } \\
\text { ż }\end{array}$ & 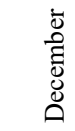 \\
\hline Tobolsk & 2.4 & 2.5 & 2.2 & 2.0 & 1.6 & 1.1 & 1.2 & 1.8 & 1.8 & 2.2 & 2.4 & 2.2 \\
\hline Tyumen & 2.8 & 2.8 & 2.7 & 2.2 & 1.5 & 1.4 & 1.4 & 2.2 & 2.1 & 2.4 & 2.7 & 2.7 \\
\hline Jalutorovsk & 2.6 & 2.6 & 2.2 & 1.7 & 1.2 & 1.2 & 1.4 & 1.8 & 2.2 & 2.2 & 2.4 & 2.6 \\
\hline Berdjuzh'e & 3.2 & 3.2 & 3.0 & 1.8 & 1.6 & 1.5 & 1.7 & 2.1 & 2.8 & 3.0 & 3.0 & 3.1 \\
\hline
\end{tabular}

Our research has shown that perched water does not stagnate in one place, but moves along the slope of the aquiclude, only at a much lower speed. Therefore, it is able to accumulate in lenses consisting of light on granulometric composition soils.

Mineralization of perched water of non-wetland areas (table.2) varies widely - from 0.1 to $5.0 \mathrm{~g} /$ liter. In some cases, mineralization can reach an impressive value of $30-50 \mathrm{~g} / \mathrm{l}$, because of the composition of soil-forming and underlying rocks. Water of the watershed plains have higher mineralization, and consist of the superficial deposits and neogene rocks. General desalination is carried out towards the lower terraces, due to the gradual leaching of water-soluble salts of the upper terraces. According to natural zones, the degree of 
mineralization increases from the taiga to the southern forest-steppe, which mainly coincides with the change in geomorphological levels. By type of salinity in the taiga zone there is chloride; in the forest-steppe zone - hydrocarbonate-sodium.

Table 2. Data of water samples analysis taken at stationary platform (2010-2014)

\begin{tabular}{|l|c|c|c|c|c|c|c|c|}
\hline \multirow{2}{*}{$\begin{array}{c}\text { Stationary } \\
\text { platform }\end{array}$} & \multirow{2}{*}{$\begin{array}{c}\text { Solid residue, } \\
\%\end{array}$} & \multicolumn{3}{|c|}{ Cations, $\mathrm{mg} / 1$} & \multicolumn{5}{c|}{ Anions, $\mathrm{mg} / 1$} \\
\cline { 3 - 10 } & $\mathrm{Ca}^{2+}$ & $\mathrm{Mg}^{2+}$ & $\mathrm{Na}^{+}$ & $\mathrm{CO}_{3}^{2-}$ & $\mathrm{HCO}_{3}^{-}$ & $\mathrm{CL}^{-}$ & $\mathrm{SO}_{4}^{-}$ \\
\hline Tobolsk & 0.22 & 0.08 & 0.02 & 0.01 & 0,00 & 0.32 & 0.01 & 0,00 \\
\hline Tyumen & 0.34 & 0.04 & 0.04 & 0.03 & 0.04 & 0.21 & 0.01 & 0,00 \\
\hline Jalutorovsk & 0.43 & 0.03 & 0.07 & 0.12 & 0.01 & 0.06 & 0.06 & 0.03 \\
\hline Berdjuzh'e & 24.25 & 0.63 & 1.25 & 2.68 & 0,00 & 0.48 & 6.88 & 2.45 \\
\hline
\end{tabular}

As our studies have shown, precipitation in the main territory of Western Siberia rarely reaches natural receiving waters, and seeps through the soil-ground thickness. In areas with homogeneous granulometric composition of the soil, infiltration of water occurs at great depth, on rocks of different size in granulometric composition it forms the perched water, which has a direct impact on the swelling soil and impeded construction work.

Table 3 presents the results of the granulometric composition of the Tobolsk stationary platform. The main waterproof horizon, characterized by a maximum content of silt fraction $(<0.001 \mathrm{~mm})$ begins with a depth of $280 \mathrm{~cm}$. Its origin is not associated with modern soil-forming processes that are in the top $150 \mathrm{~cm}$.

Table 3. Granulometric composition of the soil at the stationary platform "Tobolsk"

\begin{tabular}{|c|c|c|c|c|c|c|}
\hline \multirow{2}{*}{ Depth, cm } & \multicolumn{5}{|c|}{ The size of granulometric elements (mm) and their contents (\%) } \\
\cline { 2 - 8 } & $1.00-0.25$ & $0.25-0.05$ & $0.05-0.01$ & $0.01-0.005$ & $0.005-0.001$ & $\begin{array}{l}<0,00 \\
1\end{array}$ \\
\hline 10 & 8.1 & 14.4 & 42.5 & 8.5 & 8.3 & 18.2 \\
\hline 40 & 4.5 & 6.4 & 30.4 & 3.9 & 6.2 & 48.6 \\
\hline 70 & 5.5 & 8.5 & 41.0 & 4.6 & 5.4 & 35.0 \\
\hline 90 & 5.5 & 7.0 & 43.2 & 3.5 & 6.2 & 34.6 \\
\hline 110 & 7.8 & 6.8 & 41.0 & 7.4 & 5.7 & 31.3 \\
\hline 130 & 8.4 & 6.5 & 38.3 & 5.0 & 8.3 & 33.5 \\
\hline 160 & 10.1 & 7.3 & 36.4 & 6.2 & 4.8 & 35.2 \\
\hline 190 & 8.5 & 8.4 & 34.8 & 7.3 & 7.5 & 33.5 \\
\hline 210 & 6.4 & 7.6 & 39.5 & 5.7 & 7.5 & 33.3 \\
\hline 250 & 5.7 & 5.8 & 37.7 & 6.9 & 5.5 & 38.4 \\
\hline 280 & 2.9 & 9.5 & 25.6 & 10.0 & 7.8 & 44.2 \\
\hline 300 & 3.5 & 12.5 & 24.1 & 8.9 & 7.5 & 43.5 \\
\hline 350 & 5.4 & 13.0 & 25.3 & 9.5 & 8.4 & 48.4 \\
\hline
\end{tabular}

However, such a high content of silt and dusty particles is a significant obstacle to water infiltration. The situation is aggravated by a large difference in the granulometric composition between the aquiclude and the overlying layer $(190 \mathrm{~cm})$, which is 
characterized by a lighter granulometric composition. In the profile distribution of silt particles, changes under the action of eluvial-illuvial processes are also noticeable, which can not cause the formation of the perched water in close proximity to the surface, but contributes to surface overwetting. In the conditions of Western Siberia it will only strengthen soil swelling. Therefore, in the sub-taiga zone in the design of highways it is recommended that this layer is completely removed, and instead use a coarse sand or fine gravel fraction. In forming the slopes, best ground will be artificial fertile soils made of sand, peat and clay $[9,13]$.

In the southern forest-steppe, the manifestation of the illuvial processes is not expressed as in the sub-taiga zone, so the clay of relic origin serves as an aquiclude. At the stationary platform " Berdjuzh'e " it is located at a depth of $350 \mathrm{~cm}$ (table.4). Above this mark, the soil is characterized by a homogeneous medium and heavy-loamy granulometric composition. This creates all the prerequisites for raising water on the capillaries almost to the surface of the soil, which increases the swelling of such soils to the full depth of freezing.

Table 4. Granulometric composition of the soil at the stationary platform "Berdjuzh'e"

\begin{tabular}{|c|c|c|c|c|c|c|}
\hline \multirow{2}{*}{$\begin{array}{c}\text { Depth, } \\
\text { cm }\end{array}$} & \multicolumn{6}{|c|}{ The size of granulometric elements (mm) and their contents (\%) } \\
\cline { 2 - 7 } & $1.00-0.25$ & $0.25-0.05$ & $0.05-0.01$ & $0.01-0.005$ & $0.005-0.001$ & $\begin{array}{l}<0,0 \\
01\end{array}$ \\
\hline 10 & 5.6 & 5.3 & 20.1 & 5.5 & 24.9 & 38.6 \\
\hline 40 & 7.1 & 5.1 & 13.0 & 4.6 & 31.1 & 39.1 \\
\hline 80 & 6.0 & 6.9 & 16.0 & 6.8 & 28.0 & 36.3 \\
\hline 120 & 4.7 & 25.5 & 5.1 & 13.0 & 13.7 & 38.0 \\
\hline 160 & 2.6 & 22.4 & 7.3 & 10.8 & 20.6 & 36.3 \\
\hline 210 & 4.0 & 25.6 & 4.0 & 16.1 & 15.4 & 34.9 \\
\hline 270 & 6.1 & 25.9 & 5.4 & 7.3 & 31.7 & 23.6 \\
\hline 350 & 2.5 & 2.6 & 5.7 & 10.3 & 38.6 & 40.3 \\
\hline 400 & 5.7 & 5.3 & 4.7 & 12.4 & 29.1 & 42.8 \\
\hline
\end{tabular}

To determine the degree of soil swelling it is necessary to know not only the depth of groundwater, but also the actual humidity before freezing. In the conditions of Western Siberia, according to average annual data, it falls on the end of October, the beginning of November. Our research has shown that the moisture content in the zone of freezing in the stationary platforms varies considerably over the years and on a territorial basis. Actual humidity in the "Tobolsk" stationary platform in the first half of November varied between $18.3-30.3 \%$ of soil mass. Capillary fringe was located at a depth of $90 \mathrm{~cm}$ from the soil surface (Fig.1). The water content in the layer of 90-130 cm corresponds to the values of capillary moisture capacity. It should be noted that there is another wet layer formed at a depth of $40 \mathrm{~cm}$. The cause of the moisture could not be perched water, as it separates the layers with less humidity $(70-90 \mathrm{~cm})$. The high degree of moisture is due to lower water permeability because of the presence of the illuvial horizon in the gray forest soil. In wet years, this horizon can cause the manifestation of soil swelling to the maximum extent.

At the Tyumen stationary platform, the actual moisture content in the layer of 40-130 $\mathrm{cm}$ was slightly higher than the values of capillary moisture capacity and varied within $25.8-30.6 \%$ by weight. The humus layer was characterized by loose addition, which positively affected the humidity, which was $30.0 \%$, at $40.1 \%$ of the soil mass of capillary moisture capacity. Our calculations have shown that the capillary fringe is formed slightly 
above $40 \mathrm{~cm}$ from the soil surface. A well-developed capillary network in soils homogeneous in granulometric composition explains this. The absence of a full illuvial horizon, as in light gray forest soil ("Tobolsk" stationary platform), leads to the rise of water from perched water almost to the surface of the soil, thereby forming a swelling soil almost from the surface.

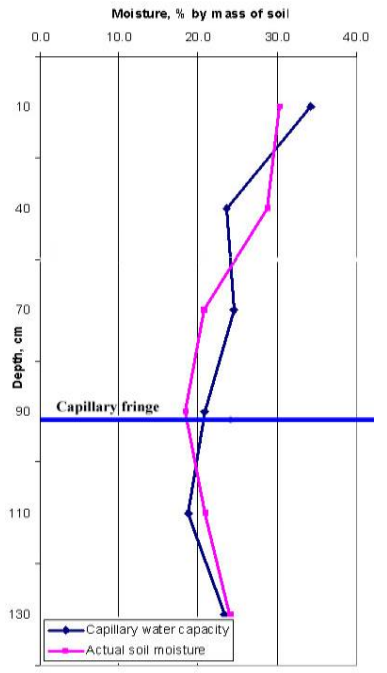

Stationary platform "Tobolsk"
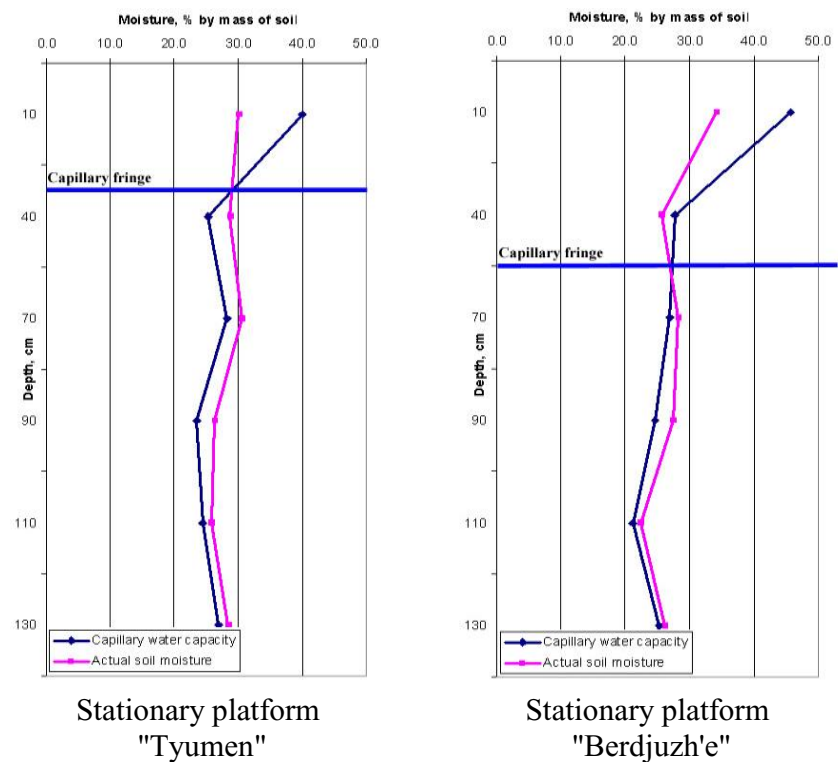

Fig. 1. Actual soil moisture in the first decade of November at the studied platforms (20102014), mm by weight of the soil

In the southern forest-steppe of Western Siberia perched water usually lies deeper, which is due to the peculiarities of the geomorphological structure of the region. However, the manifestation of salinity can impose a certain imprint on the soil swelling. At the Berdjuzh'e stationary platform capillary fringe over perched water is formed at a depth of $50 \mathrm{~cm}$. Below this mark, the actual humidity before freezing the soil coincides with the values corresponding to capillary water capacity. In the layer of $0-50 \mathrm{~cm}$, soil moisture is completely depends on precipitation, the excess of which will be delayed in the humus layer.

\section{Conclusion}

On the basis of the system analysis of granulometric composition and physical properties of soils, taking into account the peculiarities of the geomorphology of the region and climate, it was found that soil swelling is a regional feature of Western Siberia and can occupy vast territories. The process of the soil swelling due to the presence of perched water at a depth of 2 to 5 meters. The exit to the surface of neogene clays, which are a natural aquiclude, leads to the formation of perched water with a minimum depth of 1 meter in the North of Western Siberia and up to 5 meters in the forest-steppe zone. Swelling soils are characterized by a mostly homogeneous middle and heavy loam granulometric composition, able to lift water by capillary action to a height of 1-3 meters. In conditions of deep freezing it makes the soil much swelling, and the presence of soluble salts causes a cyclical process of freezing and thawing throughout the winter period. In the roads construction in Western Siberia, it is necessary to take into account the regional 
characteristics of the soil and avoid filling the canvas and slopes with soil of the same granulometric composition. The most effective measure against soil swelling will be the creation of protective screens of coarse-clastic material (fine gravel), which interrupt the capillary network and prevent the penetration of water from the perched water in the area to the roadbed. The use of pavement in the roads construction of large thickness, preventing the freezing of the base, in the conditions of Western Siberia, will be ineffective. High occurrence of perched water and severe winters will inevitably lead to the freezing of the canvas and its destruction in a short time.

\section{References}

1. V. Romanov, E.M. Myshakin, Experimental Studies: Clay Swelling (EDS Greenhouse Gases and Clay Minerals, Green Energy and Technology, 2017). doi.org/10.1007/9783-319-12661-6

2. Sri Rambabu, T., Prasada Raju, G.V.R., Sivapullaiah, P.V. Solid, Indian Geotechnical Journal. 47, 537-541 (2017), doi.org/10.1007/s40098-017-0279-x

3. L.N. Skipin, V.S. Petuhova, E.A. Romanenko, Procedia Engineering. 189, 593-597 (2017), doi.org/10.1016/j.proeng.2017.05.094

4. D.I. Eremin, D.V. Eremina, IOP Conference Series: Earth and Environmental Science. 90, 012111 (2017), doi.org/10.1088/1755-1315/90/1/012111

5. A.S. Motorin, A.V. Bukin, A.V. Iglovikov, IOP Conference Series: Earth and Environmental Science. 90, 12053 (2017), doi.org/10.1088/1755-1315/90/1/012053

6. D.I. Eremin, IOP Conference Series: Earth and Environmental Science. 90, 12021 (2017), doi.org/10.1088/1755-1315/90/1/012021

7. A.V. Iglovikov, Procedia Engineering. 165, 800-805 (2016), DOI: $10.1016 /$ j.proeng.2016.11.778

8. D.I. Eremin, D.V. Eremina, IOP Conference Series: Earth and Environmental Science. 90, 012111 (2017) DOI: 10.1088/1755-1315/90/1/012111

9. D.I. Eremin, D.V. Eremina, MATEC Web Conf. 106, 01044 (2017), DOI:10.1051/matecconf/201710601044

10. I. Kuhling, D. Redozubov, G. Broll, D. Trautz, Soil \& Tillage Research. 170, 43-52 (2017), DOI: 10.1016/j.still.2017.02.009

11. D.I. Eremin, Eurasian Soil Science. 49(5), 538-545 (2016), DOI: $10.1134 / \mathrm{S} 1064229316050033$

12. Wijaya, E.C. Leong, Indian Geotechnical Journal. 47, 537-541 (2016), doi.org/10.1007/s40098-015-0172-4 